\title{
Experimental Study on Energy and Exergy Analysis of a Counter Hollow Fiber Membrane-based Humidifier
}

\author{
Zhipeng He, Caihang Liang* \\ School of Mechano-Electronic Engineering, Guilin University of Electronic Technology, Guilin, China \\ Email address: \\ hezhipeng102@foxmail.com (Zhipeng He), lianghang@guet.edu.cn (Caihang Liang) \\ ${ }^{*}$ Corresponding author
}

To cite this article:

Zhipeng He, Caihang Liang. Experimental Study on Energy and Exergy Analysis of a Counter Hollow Fiber Membrane-based Humidifier. International Journal of Energy and Power Engineering. Vol. 9, No. 6, 2020, pp. 95-107. doi: 10.11648/j.ijepe.20200906.12

Received: November 19, 2020; Accepted: December 1, 2020; Published: December 16, 2020

\begin{abstract}
The counter hollow fiber membrane-based humidifier is used for air humidification, which avoids the problem of liquid droplets carryover in traditional liquid humidification technology. In this study, an experimental rig was established for the hollow fiber membrane humidification system. The effects of air mass flow rate, air temperature, air relative humidity, water mass flow rate, water temperature on air humidity ratio increase, air temperature difference, power consumption per unit of humidification, humidification efficiency, energy efficiency, exergy destruction and exergy efficiency were experimentally investigated using the energy and exergy method. The results reveal the enhancement of the exergy efficiency with the increase in inlet air relative humidity, inlet air dry bulb temperature, air mass flow rate, and water mass flow rate. The results show that the humidification performance of the system is strongly influenced by the water temperature, while the humidification effect is more significant for the low temperature and low air humidity. It was found that as the relative humidity and dry bulb temperature of the air increased, the exergy destruction decreased significantly and the exergy efficiency increased. Increasing the air mass flow rate and water flow temperature resulted in an increase in both exergy destruction and exergy efficiency, while increasing the water flow rate had little effect on exergy destruction and fire efficiency. The exergy efficiency of the system ranged from 0.37 to 0.71 . The maximum exergy destruction was $3.74 \mathrm{~W}$, which occurred at air $R H_{\mathrm{a}, 1}=30 \%$, air temperature $T_{\mathrm{a}, 1}=30^{\circ} \mathrm{C}$, water temperature $T_{w, 1}=28^{\circ} \mathrm{C}$, and air and water flow rates of $32 \mathrm{~kg} / \mathrm{h}$ and $7 \mathrm{~kg} / \mathrm{h}$, respectively. The humidification efficiency of the system ranged from 0.712 to 0.925 , and the power consumption per unit of humidification ranged from $0.94 \mathrm{~g} /(\mathrm{h} \bullet \mathrm{W})$ to 12.50 $\mathrm{g} /(\mathrm{h} \cdot \mathrm{W})$.
\end{abstract}

Keywords: Hollow Fiber Membrane, Air Humidification, Exergy Efficiency, Mass Transfer

\section{Introduction}

The gas humidification module is a major component of various techniques, such as air humidification [1], fuel cell technology [2], crop storage [3], and desalination [4]. Air humidity is crucial for human health and thermal comfort. The most suitable air relative humidity for human health and thermal comfort ranges from $45 \%$ to $65 \%$ [5]. A low indoor air humidity level is recognized as an important factor in the spread of influenza in winter, which accelerates the multiplication of influenza viruses and contributes to the susceptibility to respiratory diseases [6]. Therefore, air humidification is necessary to meet the indoor humidity requirements [7].

The following different types of humidifiers have been used: steam humidifiers [8], ultrasonic humidifiers [9], packed-bed humidifiers [10], bubble columns [11], and spray towers [12]. However, the above-mentioned techniques have common shortcomings. (1) Liquid water and air are in direct contact, which may produce water droplet drifts. (2) Bacteria and molds grow on moist media surfaces and enter the air through recycled water. One alternative to direct air humidification is the application of indirect air humidification, which is called membrane-based humidification. The membrane-based humidification is an excellent solution to the carryover of liquid droplets [13]. The technology has good humidification efficiency, where humidity is easily controlled and operating costs are low. Hollow fiber membranes are highly selective in permeability. The membrane only allows the passage of water vapor and 
strictly prevents water leakage in the form of liquid, and water evaporates through the membrane wall into the air to complete humidification without water mist [14-16].

The hollow fiber membrane humidifier has gained increasing attention, and most research has focused on the fluid flow and heat and mass transfer properties of hollow fiber membrane humidifiers. Chiari et al. [17] experimentally and theoretically studied the air humidification process using a hydrophobic hollow fiber membrane humidifier and discussed a predictive model for the humidification efficiency. The humidification efficiency was found to increase with decreasing inlet air and water temperature. Bergero et al. [18] developed a numerical model to predict the heat and mass transfer through the hollow fiber membrane humidifier. Their result showed that the air humidity ratio decreases with increasing airflow and is not significantly affected by liquid flow. Zhang et al. [19] numerically and experimentally investigated the coupled heat and moisture transport in a hollow fiber membrane humidifier. With 2600 fibers inside the module, the humidification efficiency ranged from $78 \%$ to $95 \%$ when the air mass flow rate is $0.35-0.83 \mathrm{~kg} / \mathrm{h}$. Li and Zhang [20] studied the flow distribution and performance deterioration of a cross-flow and counter flow hollow fiber membrane humidifier. The humidification efficiency of a humidification module is inversely proportional to the inhomogeneity of the flow, and uneven flow will severely reduce performance. In air humidification, the humidification efficiency may be reduced by $21 \%-39 \%$ at various airflows. Huang et al. [21] conducted the fluid flow and heat transfer of the elliptical tube hollow fiber membrane humidifier. They found that the heat transfer between elliptical hollow fiber membranes arranged in series deteriorated by approximately $0.1 \%-6 \%$ compared with hollow fiber membranes. The heat transfer of elliptical hollow fiber membranes either improved or deteriorated for staggered arrangements. Bakeri et al. [22] presented a porous polyethersulfone (PES) hollow fiber membrane in the gas humidification process. The experimental studies show that water flux increases with rising flow rates of gas and liquid water and increasing gas pressure decreases water flux. Bakeri [23] fabricated and characterized PES and polyetherimide (PEI) hollow fiber membranes using various test methods. The difference in water vapor flux between the PEI and PES membranes was found to increase with rising working pressure/liquid temperature.

The concept of energy and exergy are based on the conservation of mass and energy principles and the second law of thermodynamics, respectively. Exergy analysis indicates the location, nature, and cause of energy destruction in the process. Therefore, the overall performance of this process can be effectively evaluated using the method of exergy analysis. One of the most important objectives of exergy analysis is to find meaningful efficiencies and determine the causes of exergy destruction. Numerous studies are available in the field of exergy analysis in membranes engineering. However, studies on the membrane humidifiers from an exergy standpoint are limited. Banat et al.
[24] studied exergy analysis to evaluate the exergy efficiency of "compact" and "large" solar membrane distillation units. Meng et al. [25] investigated the complete energy/exergy analysis of a hydrogen production unit through a proton exchange membrane electrolyzer. Al-Sulaiman et al. [26] examined the performance of air conditioning systems with and without air membrane heat and mass exchangers through exergy analysis to compare their performance. Huang et al. [27] investigated the thermodynamic properties of liquidliquid air gap hollow fiber membrane contactors. The two-dimensional heat and mass transfer, entropy generation, and exergy destruction models of the membrane contactor are established and numerically solved and experimentally verified. Liu et al. [28] developed a mathematical thermodynamic model of a proton exchange membrane fuel cell system to uncover the energy and exergy distribution and establish an evaluation method for the system. In addition, some studies use energy and exergy to investigate the thermodynamics of the membrane dehumidifier. Liang et al. [29] developed and solved the entropy generation and energy destruction models of the internally-cooled membrane-based liquid desiccant dehumidifier to compare the performance of various parameters based on the second law of thermodynamics. Liang and Zeng and Liang [30] proposed the optimized design of a liquid desiccant module based on hollow fiber membranes. The influence of the geometric variables of the dehumidification module on the total entropy production and the total annual cost is investigated by developing a multi-objective particle swarm algorithm. In the above-mentioned literature review, researchers are focused on the fluid flow and heat and mass transfer of the hollow fiber membrane-based humidifier, and focus on energy and exergy analysis in membranes dehumidifier and distillation. However, studies on the membrane humidifiers from an exergy standpoint are limited The authors believe that only few studies have been conducted on the energy and exergy of hollow fiber membrane humidifiers using the second law of thermodynamics. The present work aims to study the energy and exergy of the counter flow hollow fiber membrane-based humidifier based on experimental study to investigate the irreversibility of the hollow fiber membrane-based humidifier comprehensively. The effects of operating conditions (inlet air relative humidity, inlet air dry bulb temperature, air mass flow rate, water temperature, and water mass flow rate) on the system performance (air humidity ratio differences, air temperature differences, fluid flow, humidification efficiency, specific electricity consumption (SEC) of air humidification capacity, and energy and exergy efficiencies) are investigated on the basis of energy and exergy analysis. These efficiencies are regarded as parameters to evaluate the performance of hollow fiber-based humidifiers effectively.

\section{Experimental Set-up}

A schematic and photograph of the experimental set-up are shown in Figure 1 (a) and (b), respectively. The set-up comprises two loops: one for air and the other is for water. In 
the air loop, the air conditions (air temperature and humidity) are pre-regulated by air conditioning system. These conditions are then regulated with a fan before going through the air channel. The air is subsequently sent through the hollow fiber membrane for humidification and finally exited to the room. An electric heater wrapped around the stainless steel tube is used to raise the air temperature. In the water loop, the water temperature is controlled by the isothermal water bath. A throttle valve controls the variation in the water flow rate. A U-tube manometer and the platinum resistance temperature sensors (Pt-100) were respectively installed at the inlet and outlet of the humidifier to measure the corresponding water pressure difference and water temperatures. An integrated humidity and temperature sensor (SIEMENS QFM 2160) was connected to the inlet and outlet of the humidifier to measure the air relative humidity and temperature. The air pressure difference and velocity were measured by monometer (TESTO 512) and hot-wire anemometer (TESTO 735), respectively. All measurements were collected and recorded using an Aligent 34972A data acquisition unit. All the sensors and instruments are pre-calibrated, and the parameters of the measuring instrument are given in Table 1. A total of 88 experiments were conducted to test the humidification performance for different air relative humidity, air dry bulb temperature, air mass flow rate, water temperature, and mass flow rate ranges. The experimental conditions for the tests are listed in Table 2.

The hollow fiber membrane-based humidifier structure is similar to that of the cross-flow shell-and-tube heat mass exchanger, in which water and air flow on the tube inside and shell side, respectively, as shown in Figure 1 (c). Air and water stream exchange moisture through the hollow fiber membrane tubes. Considering the water stream in the tube side, a large amount of sensible heat can be removed from the air to facilitate water evaporation. Moisture permeates through the membranes and is further removed by the air stream on the shell side. The hollow fiber membranes are modified porous membranes, which effectively prevents the leakage of liquid water but selectively allows the penetration of moisture.

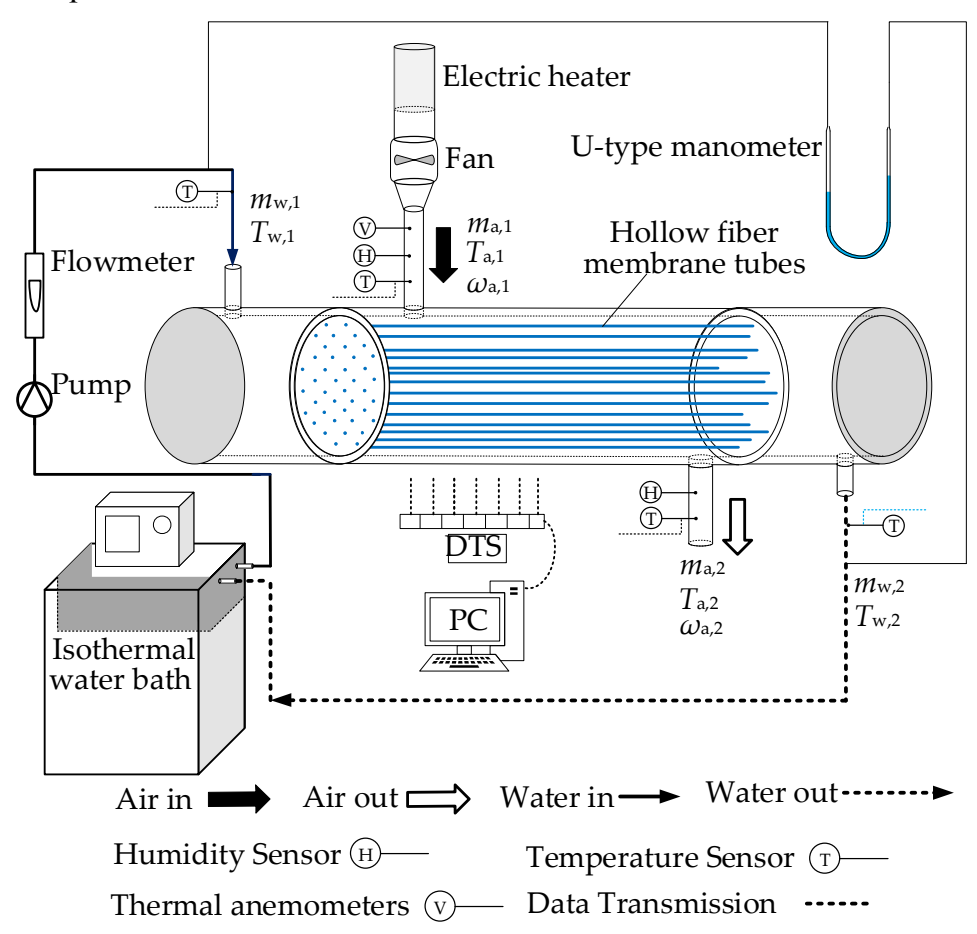

(a)

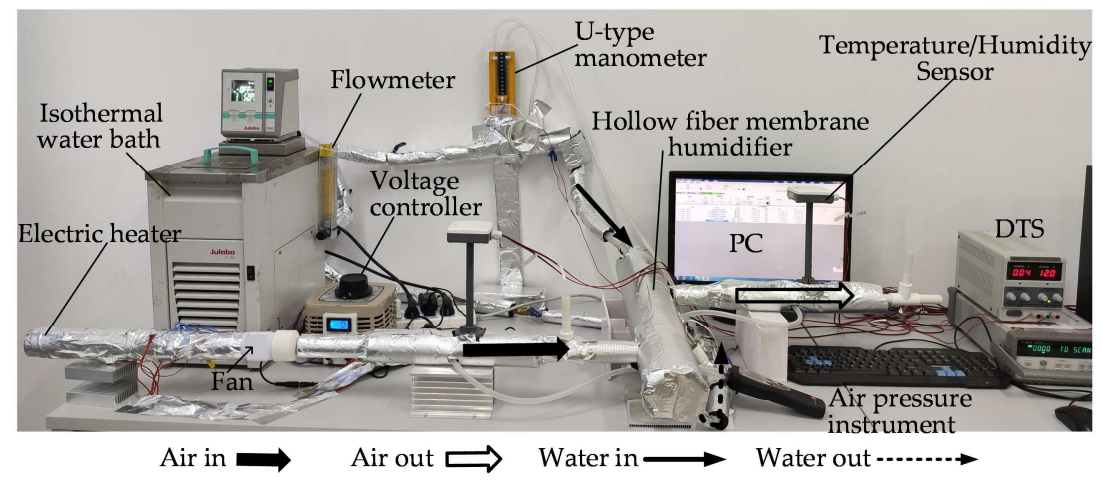

(b) 


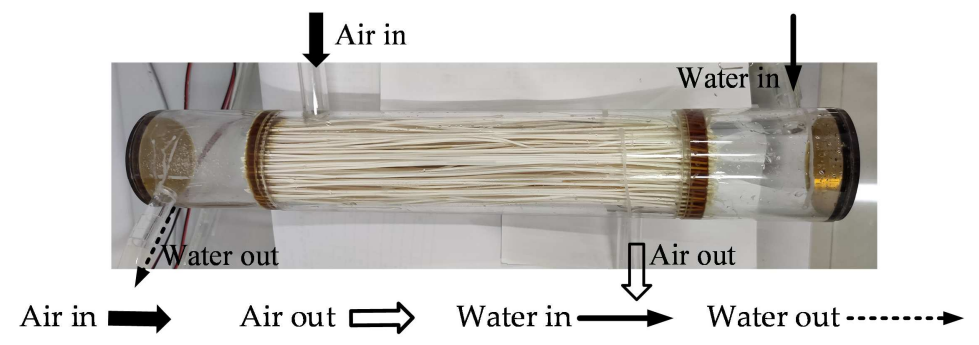

(c)

Figure 1. Test facility for the counter-flow hollow fiber membrane-based humidifier: (a) experimental rig; (b) photograph of the rig set-up, and (c) photograph of hollow fiber membrane-based humidifier.

Table 1. Parameters of experimental measuring instruments.

\begin{tabular}{llll}
\hline Sensor type & Sensor model & Sensor accuracy & Specification range \\
\hline Air velocity & TESTO 425 anemometer & $\pm 0.03 \mathrm{~m} / \mathrm{s}$ & $0-20 \mathrm{~m} / \mathrm{s}$ \\
Water flow & Flow meter LZB-10 & $\pm 4 \mathrm{~L} / \mathrm{h}$ & $16-160 \mathrm{~L} / \mathrm{h}$ \\
Water temperature & PT-100 Thermocouple & $\pm 0.15^{\circ} \mathrm{C}$ & $-20-250^{\circ} \mathrm{C}$ \\
Air relative humidity & SIEMENS QFM 2160 & $\pm 3.00 \%$ & $0-100 \%$ \\
Air temperature & TESTO 512 & $\pm 1 \mathrm{~K}$ & $-35-50^{\circ} \mathrm{C}$ \\
Air pressure & Agilent 34970A & $0.001 \mathrm{hPa}$ & $0-2 \mathrm{hPa}$ \\
Data acquisition & & $\pm 0.15 \%$ & - \\
\hline
\end{tabular}

Table 2. Experimental conditions for the test.

\begin{tabular}{lll}
\hline Studied parameter & Variables & Initial value \\
\hline Air relative humidity $(\%)$ & $30,35,40,45,50$, and 55 & $T_{\mathrm{a}, 1}=30^{\circ} \mathrm{C}, m_{\mathrm{a}, 1}=7 \mathrm{~kg} / \mathrm{h}, m_{\mathrm{w}, 1}=32 \mathrm{~kg} / \mathrm{h}$ \\
Air dry bulb temperature $\left({ }^{\circ} \mathrm{C}\right)$ & $20,22,24,26,28$, and 30 & $R H_{\mathrm{a}, 1}=40 \%, m_{\mathrm{a}, 1}=7 \mathrm{~kg} / \mathrm{h}, m_{\mathrm{w}, 1}=32 \mathrm{~kg} / \mathrm{h}$ \\
Air mass flow rate $(\mathrm{kg} / \mathrm{h})$ & $3,4,5,6$, and 7 & $T_{\mathrm{a}, 1}=30^{\circ} \mathrm{C}, R H_{\mathrm{a}, 1}=40 \%, m_{\mathrm{w}, 1}=32 \mathrm{~kg} / \mathrm{h}$ \\
Water mass flow rate $(\mathrm{kg} / \mathrm{h})$ & $16,20,24,28$, and 32 & $T_{\mathrm{a}, 1}=30^{\circ} \mathrm{C}, R H_{\mathrm{a}, 1}=40 \%, m_{\mathrm{a}, 1}=7 \mathrm{~kg} / \mathrm{h}$ \\
Hollow fiber membrane area $\left(\mathrm{m}^{2}\right)$ & & 0.3925 \\
\hline
\end{tabular}

The uncertainty can be calculated using the uncertainty transfer formula [31], which is obtained by Equations. (1) and (2), and the measured estimate $Y$ is a function of $\mathrm{N}$ of other directly measured values $x_{1}, x_{2}, \ldots, x_{\mathrm{n}}$.

$$
\begin{gathered}
Y=f\left(x_{1}, x_{2}, \ldots, x_{\mathrm{n}}\right) \\
\delta Y=\sqrt{\left(\frac{\partial Y}{\partial Y_{1}} \delta x_{1}\right)^{2}+\left(\frac{\partial Y}{\partial Y_{2}} \delta x_{2}\right)^{2}+\ldots+\left(\frac{\partial Y}{\partial Y_{\mathrm{n}}} \delta x_{\mathrm{n}}\right)^{2}}
\end{gathered}
$$

where $\delta Y$ is the overall uncertainty in the result. $\left(x_{1}, x_{2}, x_{3}, \ldots, x_{\mathrm{n}}\right)$ are the set of measurements of directly measurable parameters.

The uncertainties for the following measurements are recorded: air temperature, $\pm 0.1^{\circ} \mathrm{C}$; air relative humidity, $\pm 2.5 \%$; pressure drop, $\pm 1 \mathrm{~Pa}$; air velocity, $\pm 2.2 \%$. The maximum relative uncertainties are determined to be $\pm 1.3 \%, \pm 2.8 \%, \pm 6.3 \%$, and $\pm 4.5 \%$ for $\varepsilon_{\mathrm{h}}, \mathrm{SEC}, \eta_{\mathrm{en}}$, and $\eta_{\mathrm{ex}}$, respectively.

\section{Data Processing}

\subsection{Performance Analysis}

The performance of hollow fiber membrane humidifiers is evaluated in accordance with the following equations.

The air temperature difference $(\Delta T)$ and humidity ratio difference $(\Delta \omega)$ between inlet and outlet air streams are the performance indicators for the evaluation of hollow fiber membrane humidifiers.

$$
\begin{aligned}
& \Delta T=T_{\mathrm{a}, 1}-T_{\mathrm{a}, 2}, \\
& \Delta \omega=\omega_{\mathrm{a}, 2}-\omega_{\mathrm{a}, 1},
\end{aligned}
$$

where $T$ is temperature $(\mathrm{K}), \omega$ is humidity ratio ( $\mathrm{g}$ water vapor/kg dry air), and subscripts "a," "1," and "2" respectively represent air, inlet, and outlet.

The air humidification efficiency $\varepsilon_{\mathrm{h}}$ :

$$
\varepsilon_{\mathrm{h}}=\frac{\omega_{\mathrm{a}, 2}-\omega_{\mathrm{a}, 1}}{\omega_{\mathrm{w}}-\omega_{\mathrm{a}, 1}} .
$$

The SEC of air humidification capacity is used as an evaluation index.

$$
\mathrm{SEC}=\frac{m_{\mathrm{w}}\left(h_{\mathrm{a}, 1}-h_{\mathrm{a}, 2}\right)}{m_{\mathrm{a}}\left(\omega_{\mathrm{a}, 2}-\omega_{\mathrm{a}, 1}\right)},
$$

where $m$ is the air mass flow rate $(\mathrm{kg} / \mathrm{h})$, and subscripts "w," represent water.

\subsection{Exergy Analysis}

The second law efficiency is defined by applying an exergy balance to the system. The saturation state parameters $\left(T_{0}, P_{0}, \omega_{0}\right)$ of moist air in the atmospheric environment are selected in this paper as the reference state points for the exergy. The saturated condition of ambient air is chosen as the dead state for humid air 
and water. For all the results shown in the next section, temperature and relative humidity of the dead state are maintained and set to $T_{0}=20^{\circ} \mathrm{C}$ and $R H_{0}=100 \%$, respectively.

The energy and mass conversation relations are satisfied among water and air streams in the hollow fiber membrane-based humidifier.

$$
\begin{gathered}
m_{\mathrm{a}, 1}=m_{\mathrm{a}, 2}, \\
m_{\mathrm{a}, 1} \omega_{\mathrm{a}, 1}+m_{\mathrm{w}, \text { evap }}=m_{\mathrm{a}, 2} \omega_{\mathrm{a}, 2}, \\
m_{\mathrm{a}, 1} h_{\mathrm{a}, 1}+m_{\mathrm{w},} h_{\mathrm{w}}=m_{\mathrm{a}, 2} h_{\mathrm{a}, 2} .
\end{gathered}
$$

The exergy balance of the air humidification process is presented by Dincer and Rosen [32]:

$$
m_{\mathrm{a}, 1}(e x)_{\mathrm{a}, 1}+m_{\mathrm{w}}(e x)_{\mathrm{w}}-m_{\mathrm{a}, 2}(e x)_{\mathrm{a}, 2}-E_{\mathrm{dest}}=0,
$$

where $E_{\text {dest }}$ denotes the exergy destruction, which can be defined as

$$
E_{\text {dest }}=T_{0} S_{\mathrm{gen}}=T_{0}\left(m_{\mathrm{a}, 2} s_{2}-m_{\mathrm{a}, 1} s_{1}-m_{\mathrm{w}, \mathrm{evap}} s_{\mathrm{w}}\right),
$$

where $s$ is the specific entropy, $\mathrm{kJ} /(\mathrm{kg} \cdot \mathrm{K})$.

The moist air is regarded as an ideal gas in exergy analysis. The exergy of moist air comprises the following three parts: temperature, chemical, and mechanical exergy [33]. The exergy expression of moist air based on the air and ambient pressures is defined as follows:

$$
\begin{gathered}
(e x)_{\mathrm{a}, \mathrm{th}}=\left(c_{\mathrm{p}, \mathrm{a}}+c_{\mathrm{p}, \mathrm{v}} \omega\right) T_{0}\left(\frac{T}{T_{0}}-1-\ln \frac{T}{T_{0}}\right), \\
(e x)_{\mathrm{a}, \mathrm{ch}}=R_{\mathrm{a}} T_{0}\left(1.608 \omega \ln \frac{\omega}{\omega_{0}}+(1+1.608 \omega) \ln \frac{1+1.608 \omega_{0}}{1+1.608 \omega}\right), \\
(e x)_{\mathrm{a}, \mathrm{me}}=(1+1.608 \omega) R_{\mathrm{a}} T_{0} \ln \frac{p}{p_{0}} .
\end{gathered}
$$

The total exergy of air streams can be expressed as

$$
(e x)_{\mathrm{a}}=(e x)_{\mathrm{a}, \mathrm{th}}+(e x)_{\mathrm{a}, \mathrm{ch}}+(e x)_{\mathrm{a}, \mathrm{me}} .
$$

The exergy expression of liquid water at an arbitrary state $(T, P)$ is expressed as follows:

$$
(e x)_{\mathrm{w}}=c_{\mathrm{p}, \mathrm{w}}\left(T_{\mathrm{w}}-T_{0}+T_{0} \ln \frac{T_{0}}{T_{\mathrm{w}}}\right)-R_{\mathrm{v}} T_{0} \ln \left(\frac{P_{\mathrm{v}, 0}}{P_{\mathrm{v}}}\right)-\Delta h_{1}\left(1-\frac{T_{0}}{T_{\mathrm{w}}}\right) .
$$

The energy efficiency $\left(\eta_{\text {en }}\right)$ of the hollow fiber membrane-based humidifier is defined as the ratio of outgoing stream energy of the air to the sum of the incoming stream energies of air and evaporated water as provided by Kanoglu [34].

$$
\eta_{\mathrm{en}}=\frac{m_{\mathrm{a}, 2} h_{\mathrm{a}, 2}}{m_{\mathrm{a}, 1} h_{\mathrm{a}, 1}+m_{\mathrm{w}, \mathrm{evap}} h_{\mathrm{w}}} .
$$

Following Ratlamwala [35], the exergy efficiency $\left(\eta_{\mathrm{ex}}\right)$ is defined by the ratio between the total exergy leaving the system and that entering the system.

$$
\eta_{\mathrm{ex}}=\frac{m_{\mathrm{a}, 2}(e x)_{\mathrm{a}, 2}}{m_{\mathrm{a}}(e x)_{\mathrm{a}, 1}+m_{\mathrm{w}, \text { evap }}(e x)_{\mathrm{w}}}=1-\frac{E_{\mathrm{dest}}}{E_{\mathrm{in}}},
$$

where the $E_{\text {in }}$ can be calculated as follows:

$$
E_{\mathrm{in}}=m_{\mathrm{a}}(e x)_{\mathrm{a}, 1}+m_{\mathrm{w}, \text { evap }}(e x)_{\mathrm{w}} .
$$

\section{Results and Discussion}

\subsection{Pressure Drop}

The effects of air and water mass flow on air and water pressure drop are shown in Figure 2. The results show that pressure drop increases with the mass flow rate in air and water increases. Rising water flow does not cause the same increase in air pressure drop. The pressure drop of air stream increases from $11 \mathrm{~Pa}$ to $21 \mathrm{~Pa}$ with the air mass flow rate from $3 \mathrm{~kg} / \mathrm{h}$ to $7 \mathrm{~kg} / \mathrm{h}$, and the pressure drop of water stream increases from $30 \mathrm{~Pa}$ to $65 \mathrm{~Pa}$ with the rising water mass flow from $16 \mathrm{~kg} / \mathrm{h}$ to $32 \mathrm{~kg} / \mathrm{h}$.

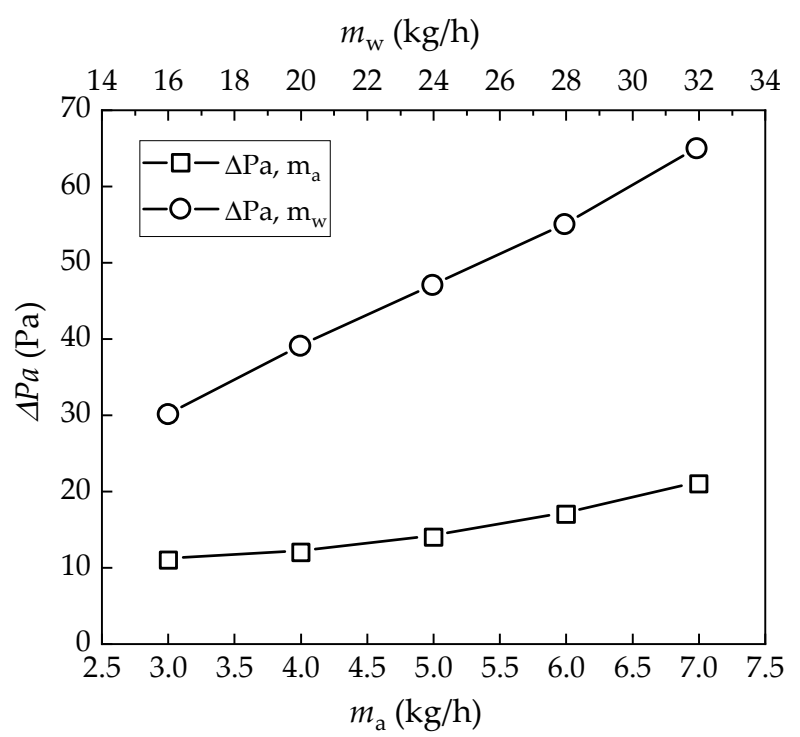

Figure 2. Effects of air and water flow rates on the pressure drops between the inlet and the outlet of the hollow fiber membrane humidifier.

\subsection{Effect of Operating Conditions on Air Humidity Ratio and Temperature Differences}

Figure 3 shows the effects of inlet air relative humidity $\left(R H_{\mathrm{a}, 1}\right)$, inlet air dry bulb temperature $\left(T_{\mathrm{a}, 1}\right)$, air mass flow rate $\left(m_{\mathrm{a}}\right)$, and water mass flow rate $\left(m_{\mathrm{w}}\right)$ under different water temperatures $\left(T_{\mathrm{w}, 1}\right)$ on the air humidity ratio difference $(\Delta \omega)$ and temperature difference $(\Delta T)$. The variations of $\Delta \omega$ and $\Delta T$ with inlet air relative humidity $\left(R H_{\mathrm{a}, 1}\right)$ and water temperature $\left(T_{\mathrm{w}, 1}\right)$ are shown in Figure 3 (a). At the same $T_{\mathrm{w}, 1}$, the $\Delta \omega$ and $\Delta T$ rapidly and slightly decrease with the increase in $R H_{\mathrm{a}, 1}$, respectively. The $\Delta \omega$ demonstrates the largest value of $11.89 \mathrm{~g} / \mathrm{kg}$ when the $R H_{\mathrm{a}, 1}$ and 
$T_{\mathrm{w}, 1}$ are $30 \%$ and $28^{\circ} \mathrm{C}$, respectively. By contrast, the $\Delta T$ shows the largest value of $7.05^{\circ} \mathrm{C}$ when the $R H_{\mathrm{a}, 1}$ and $T_{\mathrm{w}, 1}$ are $30 \%$ and $22^{\circ} \mathrm{C}$, respectively. Furthermore, at the same $T_{\mathrm{w}, 1}$, the $\Delta \omega$ and $\Delta T$ respectively decrease by approximately $44 \%-81 \%$ and $8 \%-17 \%$ with the increase in $R H_{\mathrm{a}, 1}$ from $30 \%$ to $55 \%$. This finding is due to the increase in water vapor partial pressure on the air side with the increase in $R H_{\mathrm{a}, 1}$ and the reduction in the mass transfer driving force. Therefore, $\Delta \omega$ increases and $\Delta T$ decreases. In addition, at the same $R H_{\mathrm{a}, 1}$, the $\Delta \omega$ increases with the $T_{\mathrm{w}, 1}$, while the $\Delta T$ decreases with the increase in $T_{\mathrm{w}, 1}$. Furthermore, at the same $R H_{\mathrm{a}, 1}$, the $\Delta \omega$ increases by approximately $75 \%-406 \%$ with the increase in $T_{\mathrm{w}, 1}$ from $22^{\circ} \mathrm{C}$ to $28^{\circ} \mathrm{C}$, while the $\Delta T$ decreases by approximately $62 \%-66 \%$. This condition is attributed to the increase in water vapor partial pressure with the increment in $T_{\mathrm{w}, 1}$ the enhanced driving force of mass transfer. Therefore, the $\Delta \omega$ increases. In addition, the temperature difference between the water and air streams decreases with the increase in $T_{\mathrm{w}, 1}$, and the driving force of heat transfer decreases (the sensible heat taken by water stream from the air stream decreases). Therefore, the $\Delta T$ decreases.

The variations of air humidity ratio difference $(\Delta \omega)$ and

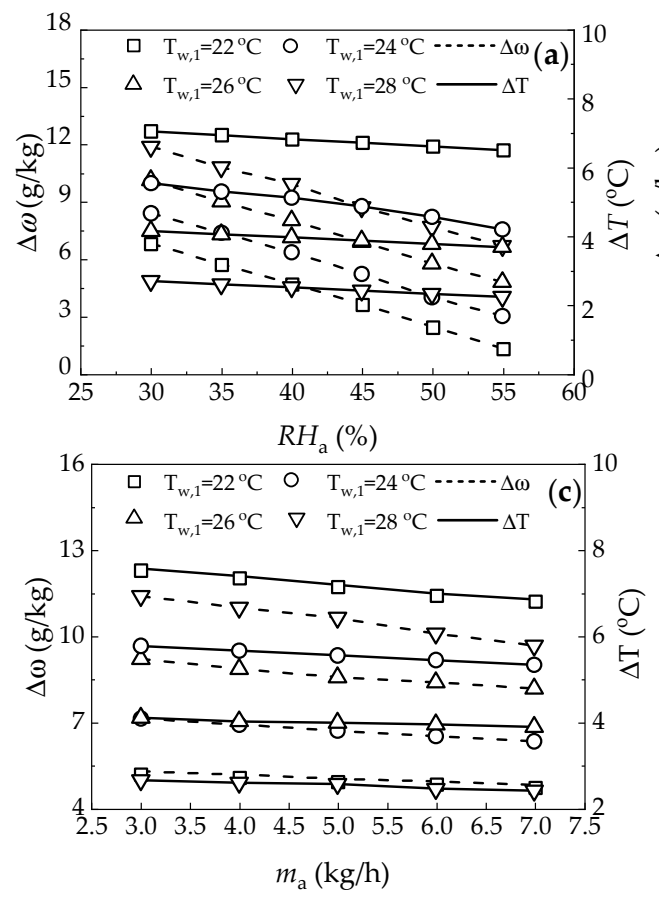

temperature difference $(\Delta T)$ with air temperature $\left(T_{\mathrm{a}, 1}\right)$ and water temperature $\left(T_{\mathrm{w}, 1}\right)$ are shown in Figure $3(\mathrm{~b})$. At the same $T_{\mathrm{w}, 1}$, $\Delta T$ and $\Delta \omega$ rapidly increase and decrease with the increase in the $T_{\mathrm{a}, 1}$, respectively. The $\Delta \omega$ demonstrates the largest value of $13.17 \mathrm{~g} / \mathrm{kg}$ when the $T_{\mathrm{a}, 1}$ and $T_{\mathrm{w}, 1}$ are $20^{\circ} \mathrm{C}$ and $28^{\circ} \mathrm{C}$, respectively. Meanwhile, the $\Delta T$ shows the largest value of $6.89^{\circ} \mathrm{C}$ when $T_{\mathrm{a}, 1}$ and $T_{\mathrm{w}, 1}$ are $30^{\circ} \mathrm{C}$ and $22^{\circ} \mathrm{C}$, respectively. Furthermore, at the same $T_{\mathrm{w}, 1}$, the $\Delta \omega$ decreases by approximately $26 \%-45 \%$ and $\Delta T$ increases by approximately $142 \%-1980 \%$ with the increase in $T_{\mathrm{a}, 1}$ from $20^{\circ} \mathrm{C}$ to $30^{\circ} \mathrm{C}$. In addition, at the same $T_{\mathrm{a}, 1}$, the $\Delta \omega$ and $\Delta T$ respectively increase and decrease with the increase in $T_{\mathrm{w}, 1}$. Furthermore, at the same $T_{\mathrm{a}, 1}$, the $\Delta \omega$ increases by approximately $60 \%-112 \%$ with the increase in $T_{\mathrm{w}, 1}$ from $22^{\circ} \mathrm{C}$ to $28^{\circ} \mathrm{C}$, while the $\Delta T$ decreases by approximately $69 \%-1311 \%$. These findings can be attributed to the following: (i) the capability of air to hold additional vapor decreases as the air temperature rises at the same relative humidity; (ii) the increase in the potential difference of temperatures between water and air due to the rising water temperature. Simultaneously, a low water temperature facilitates a strong temperature drop.

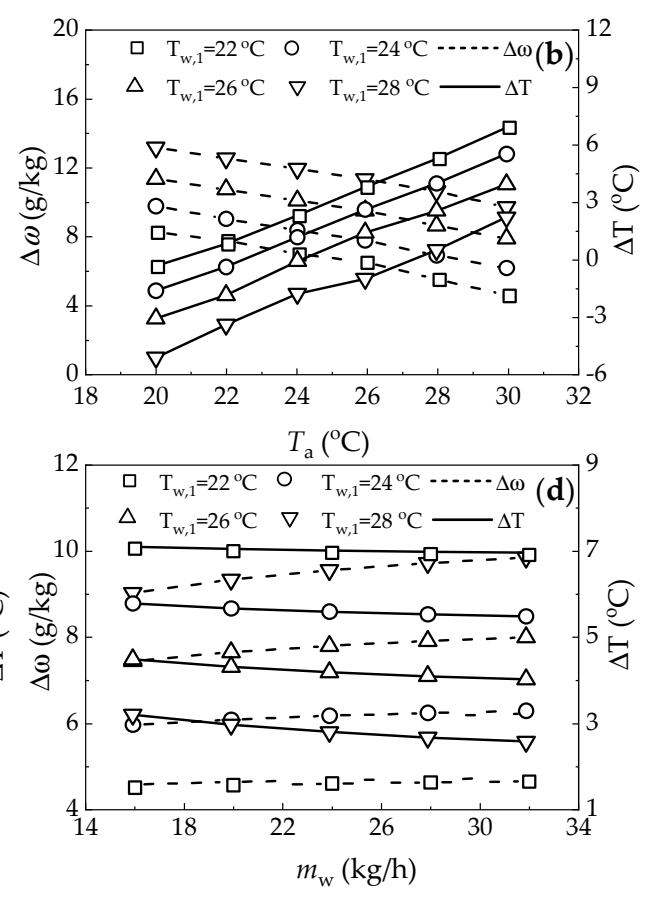

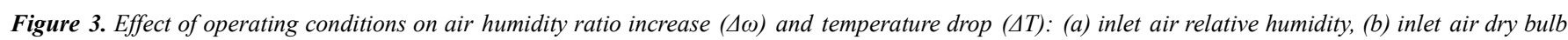
temperature, (c) air mass flow rate, and (d) water mass flow rate. 4.3 Effect of operating conditions on SEC of air humidification capacity.

Figure 3 (c) presents the variation of air humidity ratio difference $(\Delta \omega)$ and temperature difference $(\Delta T)$ with air mass flow rate $\left(m_{\mathrm{a}, 1}\right)$ and water temperature $\left(T_{\mathrm{w}, 1}\right)$. The Figure reveals that at the same $T_{\mathrm{w}, 1}$, the $\Delta \omega$ and $\Delta T$ slightly decrease with the increase in $m_{\mathrm{a}, 1}$. The $\Delta \omega$ had the largest value of $11.33 \mathrm{~g} / \mathrm{kg}$ when the $m_{\mathrm{a}, 1}$ and $T_{\mathrm{w}, 1}$ are $3 \mathrm{~kg} / \mathrm{h}$ and $28^{\circ} \mathrm{C}$, respectively. By contrast, the $\Delta T$ had the largest value of $7.54^{\circ} \mathrm{C}$ when the $m_{\mathrm{a}, 1}$ and $T_{\mathrm{w}, 1}$ are $3 \mathrm{~kg} / \mathrm{h}$ and $22^{\circ} \mathrm{C}$, respectively. Furthermore, at the same $T_{\mathrm{w}, 1}$, the $\Delta \omega$ and $\Delta T$ respectively decrease by approximately $9 \%-15 \%$ and $5 \%-10 \%$ with the increase in $m_{\mathrm{a}, 1}$ from $3 \mathrm{~kg} / \mathrm{h}$ to $7 \mathrm{~kg} / \mathrm{h}$. In addition, at the same $m_{\mathrm{a}, 1}$, the $\Delta \omega$ and
$\Delta T$ respectively increase and decrease with the increase in $T_{\mathrm{w}, 1}$. Furthermore, at the same $m_{\mathrm{a}, 1}$, the $\Delta \omega$ increases by approximately $103 \%-118 \%$ with the increase in $T_{\mathrm{w}, 1}$ from $22^{\circ} \mathrm{C}$ to $28^{\circ} \mathrm{C}$, while the $\Delta T$ decreases by approximately $62 \%-69 \%$. On the one hand, this is due to the decrease in the contact time between the air particles and the hollow fiber membrane with the increase in the $m_{\mathrm{a}, 1}$, which caused the reduction in the water evaporation rate, thus decreasing the air humidification and cooling potentials. On the other hand, the mass transfer capacity of hollow fiber films is limited, with increasing the $m_{\mathrm{a}, 1}$ the amount of water vapor obtained per unit volume of air 


\section{decreases.}

Figure 3 (d) further shows the variation of air humidity ratio difference $(\Delta \omega)$ and temperature difference $(\Delta T)$ with water mass flow $\left(m_{\mathrm{w}, 1}\right)$ and water temperature $\left(T_{\mathrm{w}, 1}\right)$. The Figure reveals that at the same $T_{\mathrm{w}, 1}$, the $\Delta \omega$ slight rises and $\Delta T$ slightly drops with the increase in the $m_{\mathrm{w}, 1}$. The $\Delta \omega$ had the largest value of $9.80 \mathrm{~g} / \mathrm{kg}$ when the $m_{\mathrm{w}, 1}$ and $T_{\mathrm{w}, 1}$ are $32 \mathrm{~kg} / \mathrm{h}$ and $28^{\circ} \mathrm{C}$, respectively. By contrast, the $\Delta T$ had the largest value of $7.05^{\circ} \mathrm{C}$ when the $m_{\mathrm{w}, 1}$ and $T_{\mathrm{w}, 1}$ are $16 \mathrm{~kg} / \mathrm{h}$ and $22^{\circ} \mathrm{C}$, respectively. This finding is attributed to the increase in Reynolds number due to the rise in the $m_{\mathrm{w}, 1}$. Consequently, the capabilities to evaporate water rate and reduce air temperature are enhanced. Furthermore, at the same $T_{\mathrm{w}, 1}$, the $\Delta \omega$ decreased by approximately $3 \%-9 \%$ with the increase in $m_{\mathrm{w}, 1}$ from $16 \mathrm{~kg} / \mathrm{h}$ to $32 \mathrm{~kg} / \mathrm{h}$, while the $\Delta T$ increased by approximately $2 \%-20 \%$. In addition, at the same
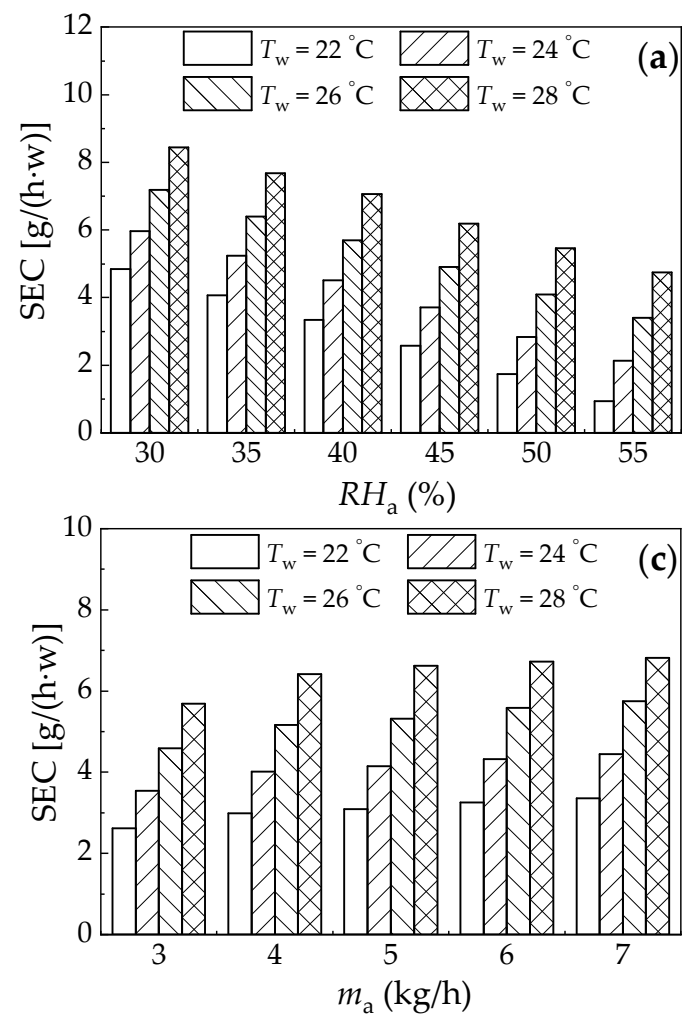

$m_{\mathrm{w}, 1}$, the $\Delta \omega$ and $\Delta T$ respectively increase and decrease with the increase in $T_{\mathrm{w}, 1}$. Furthermore, at the same $m_{\mathrm{w}, 1}$, the $\Delta \omega$ and $\Delta T$ respectively increase and decrease by approximately $99 \%-111 \%$ and $55 \%-64 \%$ with the increase in $T_{\mathrm{w}, 1}$ from $22^{\circ} \mathrm{C}$ to $28^{\circ} \mathrm{C}$. This finding is attributed to the minimal effect of the rising water mass flow rate in increasing the air-water vapor concentration gradient. Thus, the improved humidification performance due to the high water velocity had minimal effect.

The SEC of air humidification capacity is defined as the ratio between the air humidification rate and the fan and pump powers. The effects of inlet air relative humidity $\left(R H_{\mathrm{a}, 1}\right)$, inlet air dry bulb temperature $\left(T_{\mathrm{a}, 1}\right)$, air mass flow rate $\left(m_{\mathrm{a}, 1}\right)$, and water mass flow rate $\left(m_{\mathrm{w}, 1}\right)$ at different water inlet temperatures $\left(T_{\mathrm{w}, 1}\right)$ on SEC are shown in Figure 4.
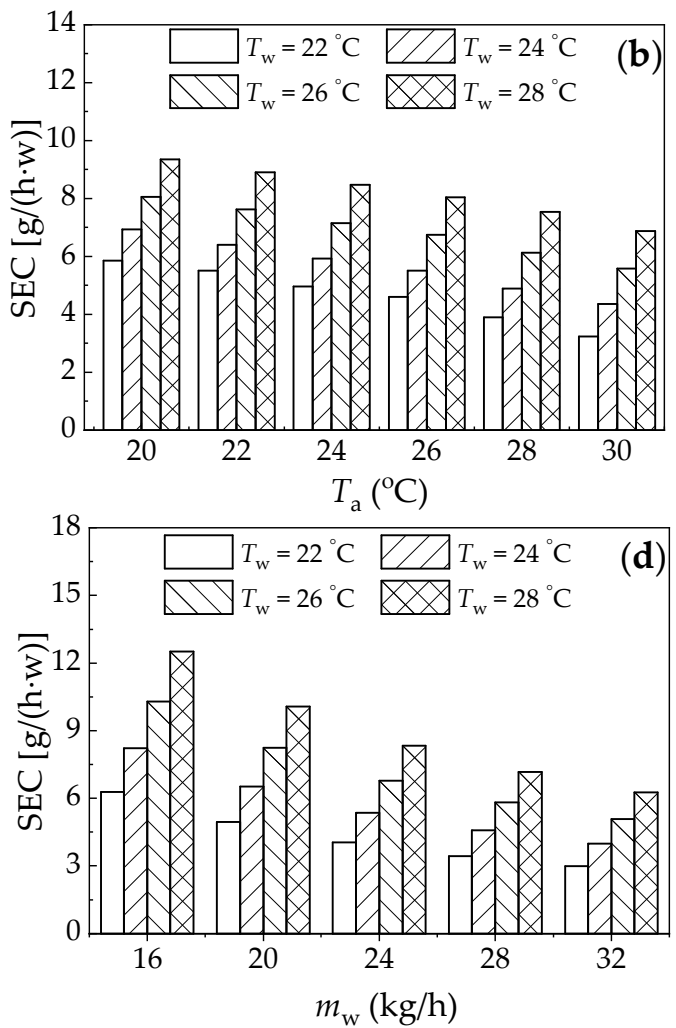

Figure 4. Effect of operating conditions on the SEC of air humidification capacity: (a) inlet air relative humidity, (b) inlet air dry bulb temperature, (c) air mass flow rate, and (d) water mass flow rate.

Figure 4 (a) shows the variation of the SEC with inlet air relative humidity $\left(R H_{\mathrm{a}, 1}\right)$ and water temperature $\left(\mathrm{T}_{\mathrm{w}, 1}\right)$. At the same $T_{\mathrm{w}, 1}$, the SEC decreased with the increase in the $R H_{\mathrm{a}, 1}$. The SEC had a maximum value of $8.44 \mathrm{~g} /(\mathrm{h} \cdot \mathrm{W})$ when the $R H_{\mathrm{a}, 1}$ and $T_{\mathrm{w}, 1}$ are $30 \%$ and $28^{\circ} \mathrm{C}$, respectively. At the same $T_{\mathrm{w}, 1}$, the SEC decreased by approximately $44 \%-81 \%$ with the increase in $R H_{\mathrm{a}, 1}$ from $30 \%$ to $55 \%$. In addition, at the same $R H_{\mathrm{a}, 1}$, the SEC increased by approximately $75 \%-406 \%$ with the increase in $T_{\mathrm{w}, 1}$ from $22^{\circ} \mathrm{C}$ to $28^{\circ} \mathrm{C}$. Figure 4 (b) demonstrates the variation of the SEC with inlet air dry bulb temperature $\left(T_{\mathrm{a}, 1}\right)$ and water temperature $\left(T_{\mathrm{w}, 1}\right)$. At the same $T_{\mathrm{w}, 1}$, the SEC decreased with the increase in the $T_{\mathrm{a}, 1}$. The SEC had the largest value of $9.35 \mathrm{~g} /(\mathrm{h} \cdot \mathrm{W})$ when the $T_{\mathrm{a}, 1}$ and $T_{\mathrm{w}, 1}$ are $20^{\circ} \mathrm{C}$ and $28^{\circ} \mathrm{C}$, respectively. Furthermore, at the same
$T_{\mathrm{w}, 1}$, the SEC decreased by approximately $26 \%-45 \%$ with the increase in $T_{\mathrm{a}, 1}$ from $20^{\circ} \mathrm{C}$ to $30^{\circ} \mathrm{C}$. At the same $T_{\mathrm{a}, 1}$, the SEC increased with the $T_{\mathrm{w}, 1}$. In addition, at the same $T_{\mathrm{a}, 1}$, the SEC increased by approximately $60 \%-112 \%$ with the increase in $T_{\mathrm{w}, 1}$ from $22^{\circ} \mathrm{C}$ to $28^{\circ} \mathrm{C}$.

Figures 4 (a)-(b) and Figures 3 (a)-(b) demonstrated the same trend with an increase in the $R H_{\mathrm{a}, 1}$ and $T_{\mathrm{a}, 1}$. This similarity can be attributed to the linear relationship between the SEC and $\Delta \omega$ when the pump and turbine power have fixed values.

Figure 4 (c) shows the increase in SEC with the air mass flow rate $\left(m_{\mathrm{a}, 1}\right)$ and water temperature $\left(T_{\mathrm{w}, 1}\right)$. At the same $T_{\mathrm{w}, 1}$, the SEC decreased with the $m_{\mathrm{a}, 1}$. The SEC had the largest value of $6.82 \mathrm{~g} /(\mathrm{h} \cdot \mathrm{W})$ when the $m_{\mathrm{a}, 1}$ and $T_{\mathrm{w}, 1}$ are $7 \mathrm{~kg} / \mathrm{h}$ and 
$28^{\circ} \mathrm{C}$, respectively. Furthermore, at the same $T_{\mathrm{w}, 1}$, the SEC decreased by approximately $20 \%-28 \%$ with the increase in $m_{\mathrm{a}, 1}$ from $3 \mathrm{~kg} / \mathrm{h}$ to $7 \mathrm{~kg} / \mathrm{h}$. At the same $m_{\mathrm{a}, 1}$, the SEC increased with $T_{\mathrm{w}, 1}$. In addition, at the same $T_{\mathrm{a}, 1}$, the SEC increased by approximately $103 \%-118 \%$ with the rise in $T_{\mathrm{w}, 1}$ from $22^{\circ} \mathrm{C}$ to $28^{\circ} \mathrm{C}$. Although Figure 3 (c) shows that the decrease in the air humidity ratio increase $(\Delta \omega)$ with the rising air mass flow, Figure 4 (c) shows the increase in the SEC with the air velocity. Therefore, the effect of the $m_{\mathrm{a}, 1}$ on the SEC is more dominant than that of the decrease in the $(\Delta \omega)$ and the increase in the fan power.

Figure $4(d)$ further shows the variation in SEC with water mass flow $\left(m_{\mathrm{w}, 1}\right)$ and water temperature $\left(T_{\mathrm{w}, 1}\right)$. At the same $T_{\mathrm{w}, 1}$, the SEC slightly dropped with the increase in the $m_{\mathrm{w}, 1}$. The SEC had the largest value of $12.50 \mathrm{~g} /(\mathrm{h} \cdot \mathrm{W})$ when the $m_{\mathrm{w}, 1}$ and $T_{\mathrm{w}, 1}$ are $16 \mathrm{~kg} / \mathrm{h}$ and $28^{\circ} \mathrm{C}$, respectively. Furthermore, at the same $T_{\mathrm{w}, 1}$, the SEC decreased by approximately $50 \%$ $53 \%$ with the increase in $m_{\mathrm{w}, 1}$ from $16 \mathrm{~kg} / \mathrm{h}$ to $32 \mathrm{~kg} / \mathrm{h}$. In addition, at the same $m_{\mathrm{w}, 1}$, the SEC increased with the $T_{\mathrm{w}, 1}$. At the same $m_{\mathrm{w}, 1}$, the SEC increased by approximately $99 \%-111 \%$ with the increase in $T_{\mathrm{w}, 1}$ from $22^{\circ} \mathrm{C}$ to $28^{\circ} \mathrm{C}$. This result also shows that the effect of pump power on SEC is more important than that of the increase in the $(\Delta \omega)$.

\subsection{Effect of Operating Conditions on Humidification Efficiency}

The humidification efficiency $\left(\varepsilon_{\mathrm{h}}\right)$ is defined by Equation
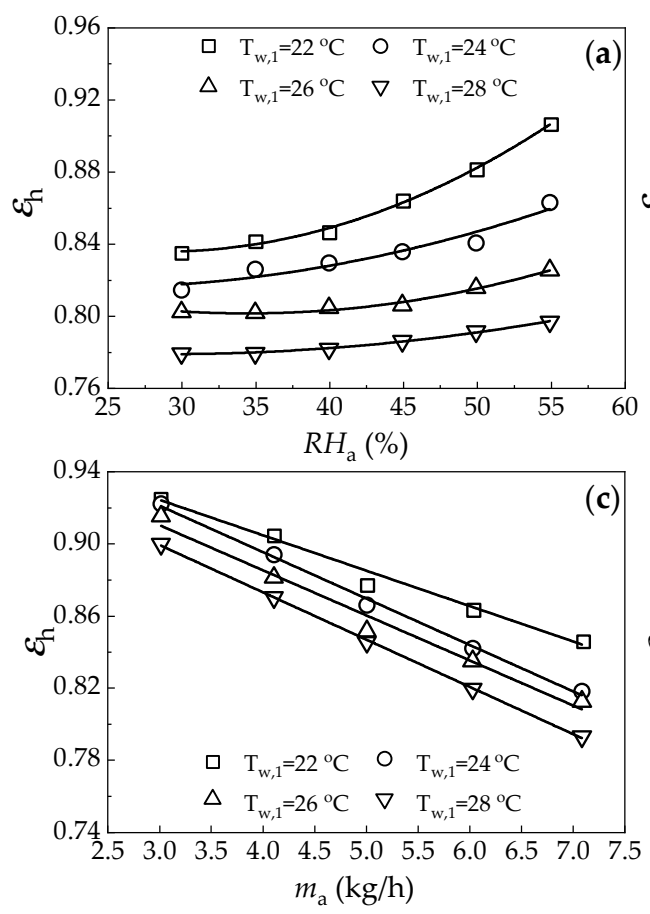

(5). Thus, the rise in the actual air humidity ratio increase leads to the increment in the humidification efficiency. Figures 3 and 4 show the rise of the air humidity ratio increase $(\Delta \omega)$ and the SEC of air humidification capacity with the increase in the water temperature $\left(T_{\mathrm{w}, 1}\right)$. This phenomenon is the result of the increase in the $T_{\mathrm{w}, 1}$, which means an increase in the amount of water vapor transfer into the air stream, thus causing the increase in the $\Delta \omega$ and the SEC, as seen in Equations (4) and (6). However, Figure 5 shows the decrease in humidification efficiency $\left(\varepsilon_{\mathrm{h}}\right)$ with the increase in the $T_{\mathrm{w}, 1}$. This decrease is attributed to the lower percentage of the increase in the $\Delta \omega$ with the $T_{\mathrm{w}, 1}$ than that of the increase in the difference in humidity ratio between water and air with the $T_{\mathrm{w}, 1}$, as seen in Equation (5).

As shown in Figure 5 and confirmed by Figure 3 , the $\Delta \omega$ decreased with the increase in inlet air relative humidity $\left(R H_{\mathrm{a}, 1}\right)$ and inlet air dry bulb temperature $\left(T_{\mathrm{a}, 1}\right)$; on the contrary, the $\varepsilon_{\mathrm{h}}$ increased with the rise of $R H_{\mathrm{a}, 1}$ and $T_{\mathrm{a}, 1}$. Moreover, the $\Delta \omega$ and the $\varepsilon_{\mathrm{h}}$ decreased with the increase in air mass flow rate $\left(m_{\mathrm{a}, 1}\right)$, and the $\Delta \omega$ and the $\varepsilon_{\mathrm{h}}$ increased with the rise in water mass flow rate $\left(m_{\mathrm{w}, 1}\right)$. Figures 5 (a)-(d) indicate the possible trend in $\varepsilon_{\mathrm{h}}$ as follows: increased by approximately $2 \%-9 \%$ with the $R H_{\mathrm{a}, 1}$ from $30 \%$ to $55 \%$ at the same $T_{\mathrm{w}, 1}$; increased $4 \%-9 \%$ with rising $T_{\mathrm{a}, 1}$ from $20^{\circ} \mathrm{C}$ to $30^{\circ} \mathrm{C}$; increased by $3 \%-9 \%$ by increasing the $m_{\mathrm{w}, 1}$ from 16 $\mathrm{kg} / \mathrm{h}$ to $32 \mathrm{~kg} / \mathrm{h}$; decreased by $9 \%-15 \%$ by increasing the $m_{\mathrm{a}, 1}$ from $3 \mathrm{~kg} / \mathrm{h}$ to $7 \mathrm{~kg} / \mathrm{h}$.

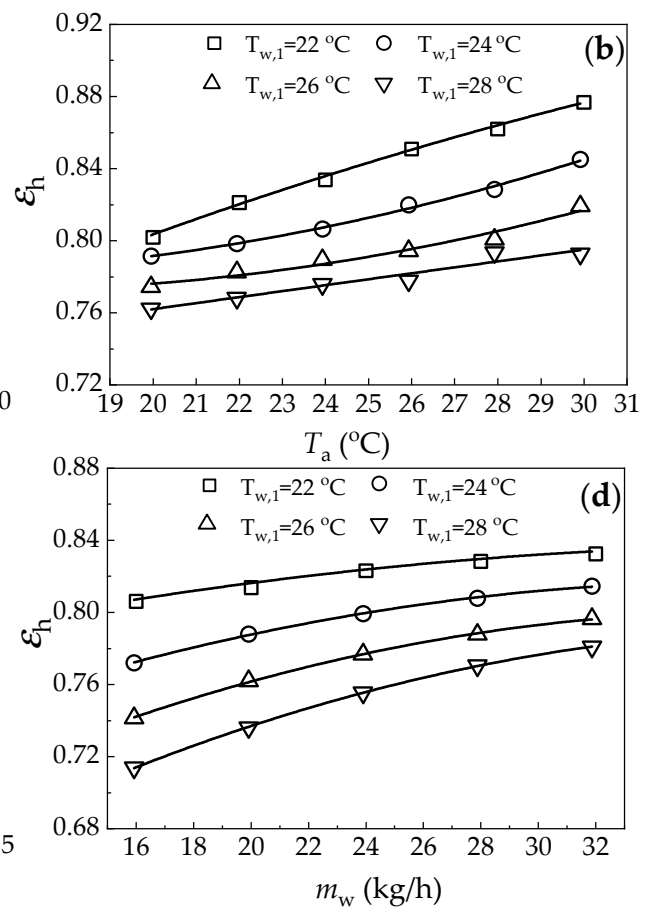

Figure 5. Effect of operating conditions on humidification efficiency $\left(\varepsilon_{h}\right)$ : (a) inlet air relative humidity, (b) inlet air dry bulb temperature, (c) air mass flow rate, and (d) water mass flow rate.

\subsection{Effect of Operating Conditions on the Exergy Destruction}

The effects of inlet air relative humidity $\left(R H_{\mathrm{a}, 1}\right)$, inlet air dry bulb temperature $\left(T_{\mathrm{a}, 1}\right)$, air mass flow rate $\left(m_{\mathrm{a}, 1}\right)$, and water mass flow rate $\left(m_{\mathrm{w}, 1}\right)$ at different water inlet temperatures $\left(T_{\mathrm{w}, 1}\right)$ on the exergy destruction $\left(E_{\text {dest }}\right)$ is shown in Figure 6.

Figure 6 (a) shows the variation in the $E_{\text {dest }}$ with inlet air relative humidity $\left(R H_{\mathrm{a}, 1}\right)$ and water temperature $\left(T_{\mathrm{w}, 1}\right)$. At the 
same $T_{\mathrm{w}, 1}$, the $E_{\mathrm{dest}}$ dropped with the increase in the $R H_{\mathrm{a}, 1}$. The $E_{\text {dest }}$ had a maximum value of $3.73 \mathrm{~W}$ when the $R H_{\mathrm{a}, 1}$ and $T_{\mathrm{w}, 1}$ are $30 \%$ and $28^{\circ} \mathrm{C}$, respectively. At the same $T_{\mathrm{w}, 1}$, the $E_{\text {dest }}$ decreased by approximately $82 \%-85 \%$ with the increase in $R H_{\mathrm{a}, 1}$ from $30 \%$ to $55 \%$. In addition, at the same $R H_{\mathrm{a}, 1}$, the $E_{\text {dest }}$ increased by approximately $41 \%-49 \%$ with the increase in $T_{\mathrm{w}, 1}$ from $22^{\circ} \mathrm{C}$ to $28^{\circ} \mathrm{C}$. Figure 6 (b) demonstrates the variation of $E_{\text {dest }}$ with inlet air dry bulb temperature $\left(T_{\mathrm{a}, 1}\right)$ and water temperature $\left(T_{\mathrm{w}, 1}\right)$. At the same $T_{\mathrm{w}, 1}$, the $E_{\text {dest }}$ decreased with the increase in the $T_{\mathrm{a}, 1}$. The $E_{\text {dest }}$ had the largest value of $3.51 \mathrm{~W}$ when the $T_{\mathrm{a}, 1}$ and $T_{\mathrm{w}, 1}$ are $20^{\circ} \mathrm{C}$ and $28^{\circ} \mathrm{C}$, respectively. Furthermore, at the same $T_{\mathrm{w}, 1}$, the $E_{\text {dest }}$ decreased by approximately $46 \%-49 \%$ with the increase in $T_{\mathrm{a}, 1}$ from $20^{\circ} \mathrm{C}$ to $30^{\circ} \mathrm{C}$. At the same $T_{\mathrm{a}, 1}$, the $E_{\text {dest }}$ increased with the $T_{\mathrm{w}, 1}$. In addition, at the same $T_{\mathrm{a}, 1}$, the $E_{\text {dest }}$ increased by approximately $30 \%-40 \%$ with the increase in $T_{\mathrm{w}, 1}$ from $22^{\circ} \mathrm{C}$ to $28^{\circ} \mathrm{C}$. This finding can be attributed to the fact that the water vapor pressure on the air side increases with an increase in the $R H_{\mathrm{a}, 1}$ ( $T_{\mathrm{a}, 1}$ remains constant), and the water vapor pressure difference between air and water decreases and the mass transfer capacity decreases. Therefore, the amount of water vapor transmission decreases, and the exergy loss decreases. At the same time, the $T_{\mathrm{a}, 1}$ increases $\left(R H_{\mathrm{a}, 1}\right.$ remains constant) with the same trend. Therefore, $E_{\mathrm{dest}}$
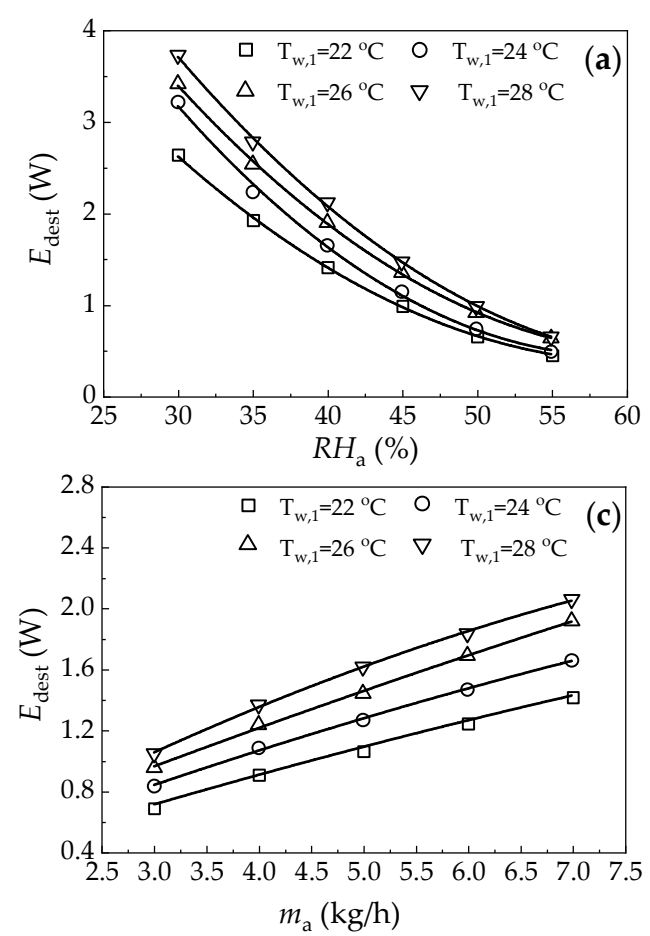

decreased with the increase in $T_{\mathrm{a}, 1}$ and $R H_{\mathrm{a}, 1}$.

The variation of the air mass flow rate $\left(m_{\mathrm{a}, 1}\right)$ on the exergy destruction $\left(E_{\text {dest }}\right)$ is shown in Figure $6(\mathrm{c})$, where the $E_{\text {dest }}$ slightly increases with the $m_{\mathrm{a}, 1}$. The $E_{\mathrm{dest}}$ has the largest value of 2.04 when the $m_{\mathrm{a}, 1}$ and $T_{\mathrm{w}, 1}$ are $7 \mathrm{~kg} / \mathrm{h}$ and $28^{\circ} \mathrm{C}$, respectively. Furthermore, at the same $T_{\mathrm{w}, 1}$, the $E_{\text {dest }}$ increases by approximately $98 \%-106 \%$ with the increase in $m_{\mathrm{a}, 1}$ from $3 \mathrm{~kg} / \mathrm{h}$ to $7 \mathrm{~kg} / \mathrm{h}$. At the same $m_{\mathrm{a}, 1}$, the $E_{\text {dest }}$ increases by approximately $44 \%-50 \%$ with the increase in $T_{\mathrm{w}, 1}$ from $22^{\circ} \mathrm{C}$ to $28^{\circ} \mathrm{C}$. This finding shows that $m_{\mathrm{a}, 1}$ accounts for a large proportion of the effect of the $E_{\text {dest }}$, as in Equations. (8) and (11).

Figure 6(d) illustrates the impact of the water mass flow rate $\left(m_{\mathrm{w}, 1}\right)$ on the exergy destruction $\left(E_{\text {dest }}\right)$, where the $E_{\text {dest }}$ virtually remains constant with the increase in the $m_{\mathrm{w}, 1}$. The $E_{\text {dest }}$ has the largest value of 2.07 when the $m_{\mathrm{w}, 1}$ and $T_{\mathrm{w}, 1}$ are $32 \mathrm{~kg} / \mathrm{h}$ and $28^{\circ} \mathrm{C}$, respectively. Furthermore, at the same $T_{\mathrm{w}, 1}$, the $\eta_{\mathrm{ex}}$ increases approximately $2 \%-4 \%$ with the increase in $m_{\mathrm{w}, 1}$ from $16 \mathrm{~kg} / \mathrm{h}$ to $32 \mathrm{~kg} / \mathrm{h}$. At the same $m_{\mathrm{w}, 1}$, the $E_{\text {dest }}$ increases approximately $45 \%-48 \%$ with the increase in $T_{\mathrm{w}, 1}$ from $22^{\circ} \mathrm{C}$ to $28^{\circ} \mathrm{C}$. This finding can be attributed to the fact that the water-side convective heat transfer coefficient increases with an increase in the $m_{\mathrm{w}, 1}$, whereby more heat can be transferred to the air and the exergy loss increases.
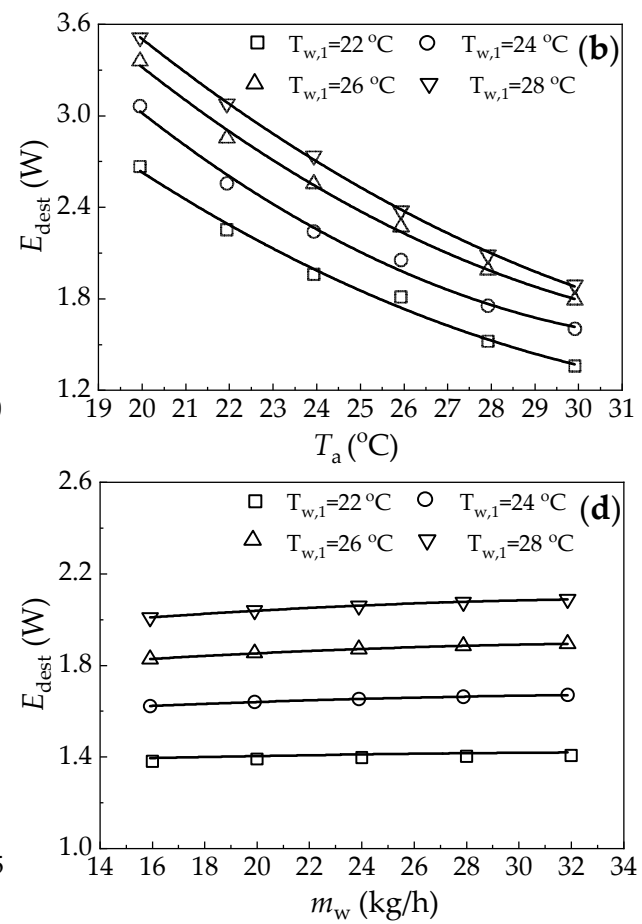

Figure 6. Effect of operating conditions on the exergy destruction ( $\left.E_{\text {dest }}\right)$ : (a) inlet air relative humidity, (b) inlet air dry bulb temperature, (c) air mass flow rate, and (d) water mass flow rate.

\subsection{Effect of Operating Conditions on Exergy and Energy Efficiencies}

Figure 7 shows the effects of inlet air relative humidity $\left(R H_{\mathrm{a}, 1}\right)$, inlet air dry bulb temperature $\left(T_{\mathrm{a}, 1}\right)$, air mass flow rate $\left(m_{\mathrm{a}}\right)$, and water mass flow rate $\left(m_{\mathrm{w}}\right)$ under different water temperatures $\left(T_{\mathrm{w}, 1}\right)$ on the exergy efficiency $\left(\eta_{\mathrm{ex}}\right)$. The results reveal the increase in exergy efficiency $\left(\eta_{\mathrm{ex}}\right)$ with increasing water temperature $\left(T_{\mathrm{w}, 1}\right)$. This phenomenon can be attributed to the significant enhancement of the heat transfer between air and water and an increase in exergy destruction due to the rising the $T_{\mathrm{w}, 1}$. However, the exergy entering the system also increases simultaneously with a larger percentage than the exergy destruction, increasing exergy efficiency as the water temperature rises.

The variations of the exergy efficiency $\left(\eta_{\mathrm{ex}}\right)$ with inlet air 
relative humidity $\left(R H_{\mathrm{a}, 1}\right)$ and water temperature $\left(T_{\mathrm{w}, 1}\right)$ are shown in Figure 7 (a). The Figure shows that at the same $T_{\mathrm{w}, 1}$, the $\eta_{\mathrm{ex}}$ slightly increases with the $R H_{\mathrm{a}, 1}$. The $\eta_{\mathrm{ex}}$ has the largest value of 0.71 when the $R H_{\mathrm{a}, 1}$ and $T_{\mathrm{w}, 1}$ are $55 \%$ and $28^{\circ} \mathrm{C}$, respectively. Furthermore, at the same $T_{\mathrm{w}, 1}$, the $\eta_{\mathrm{ex}}$ increases by approximately $15 \%-18 \%$ with the rising $R H_{\mathrm{a}, 1}$ from $30 \%$ to $55 \%$. At the same $R H_{\mathrm{a}, 1}$, the $\eta_{\mathrm{ex}}$ increases by approximately $16 \%-90 \%$ with the increase in $T_{\mathrm{w}, 1}$ from $22^{\circ} \mathrm{C}$ to $28^{\circ} \mathrm{C}$. Figure 7 (b) illustrates the variation of $\eta_{\mathrm{ex}}$ with air temperature $\left(T_{\mathrm{a}, 1}\right)$ and water temperature $\left(T_{\mathrm{w}, 1}\right)$. The Figure shows the insignificant increase in the $\eta_{\mathrm{ex}}$ with the increase in the $T_{\mathrm{a}, 1}$ at the same $T_{\mathrm{w}, 1}$. The $\eta_{\mathrm{ex}}$ has the largest value of 0.60 when the $T_{\mathrm{a}, 1}$ and $T_{\mathrm{w}, 1}$ are $30^{\circ} \mathrm{C}$ and $28^{\circ} \mathrm{C}$, respectively. Furthermore, at the same $T_{\mathrm{w}, 1}$, the $\eta_{\mathrm{ex}}$ increases by approximately $7 \%-21 \%$ with the increase in $T_{\mathrm{a}, 1}$ from $20^{\circ} \mathrm{C}$ to $30^{\circ} \mathrm{C}$. At the same $T_{\mathrm{a}, 1}$, the $\eta_{\mathrm{ex}}$ increases approximately by $15 \%$ $31 \%$ with the increase in $T_{\mathrm{w}, 1}$ from $22^{\circ} \mathrm{C}$ to $28^{\circ} \mathrm{C}$. This finding can be attributed to the increase in the exergy destruction of the air (the decrease in the heat and mass transfer coefficient of the supply air stream causes a decrease in the exergy destruction) with the increase in the $R H_{\mathrm{a}, 1}$ and the $T_{\mathrm{a}, 1}$.

The variation of the air mass flow rate $\left(m_{\mathrm{a}, 1}\right)$ on the exergy efficiency $\left(\eta_{\mathrm{ex}}\right)$ is shown in Figure 7 (c), where the $\eta_{\mathrm{ex}}$ slightly increases with the $m_{\mathrm{a}, 1}$. The $\eta_{\mathrm{ex}}$ has the largest value of 0.59 when the $m_{\mathrm{a}, 1}$ and $T_{\mathrm{w}, 1}$ are $7 \mathrm{~kg} / \mathrm{h}$ and $28^{\circ} \mathrm{C}$, respectively. Furthermore, at the same $T_{\mathrm{w}, 1}$, the $\eta_{\mathrm{ex}}$ increases by approximately $0.8 \%-2.3 \%$ with the increase in $m_{\mathrm{a}, 1}$ from $3 \mathrm{~kg} / \mathrm{h}$ to $7 \mathrm{~kg} / \mathrm{h}$. At the same $m_{\mathrm{a}, 1}$, the $\eta_{\mathrm{ex}}$ increases by approximately $29 \%-30 \%$ with the increase in $T_{\mathrm{w}, 1}$ from $22^{\circ} \mathrm{C}$ to $28^{\circ} \mathrm{C}$. This condition is due to the increase in the heat transfer rate, mass transfer rate, friction, and pressure drop with the rising air mass flow rate.
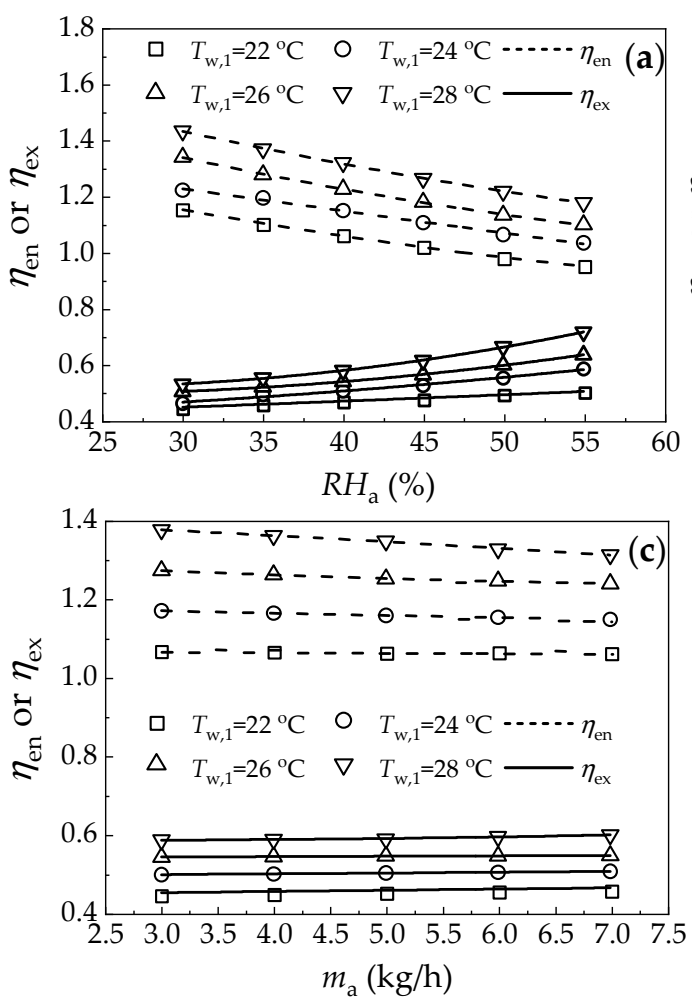

Increasing all these parameters causes an increase in the exergy destruction $\left(E_{\text {dest }}\right)$ and exergy entering in the system $\left(E_{\text {in }}\right)$. However, the percentage of the increase in the $E_{\text {dest }}$ with air mass flow rate is lower than that of the increase in the $E_{\text {in }}$ and the exergy efficiency.

Figure 7 (d) illustrates the impact of the water mass flow rate $\left(m_{\mathrm{w}, 1}\right)$ on the exergy efficiency $\left(\eta_{\mathrm{ex}}\right)$, where the $\eta_{\mathrm{ex}}$ increases with the $m_{\mathrm{w}, 1}$. The $\eta_{\mathrm{ex}}$ shows the largest value of 0.57 when the $m_{\mathrm{w}, 1}$ and $T_{\mathrm{w}, 1}$ are $32 \mathrm{~kg} / \mathrm{h}$ and $28{ }^{\circ} \mathrm{C}$, respectively. Furthermore, at the same $T_{\mathrm{w}, 1}$, the $\eta_{\mathrm{ex}}$ increases by approximately $1 \%-3 \%$ with the increase in $m_{\mathrm{w}, 1}$ from 16 $\mathrm{kg} / \mathrm{h}$ to $32 \mathrm{~kg} / \mathrm{h}$. At the same $m_{\mathrm{w}, 1}$, the $\eta_{\mathrm{ex}}$ increases by approximately $29 \%-30 \%$ with the rising $T_{\mathrm{w}, 1}$ from $22^{\circ} \mathrm{C}$ to $28^{\circ} \mathrm{C}$. This finding can be attributed to an increase in the water evaporation rate and the air temperature drop with the water mass flow rate $\left(m_{\mathrm{w}, 1}\right)$. This phenomenon raises the inlet exergy and decreases the exit exergy of the hollow fiber membrane humidifier.

Figure 7 also shows the results of the energy efficiency $\left(\eta_{\mathrm{en}}\right)$ of the hollow fiber membrane humidifier obtained in the different tests. Theoretically, the $\eta_{\text {en }}$ should be $100 \%$ for air passage through the hollow fiber membrane humidifier in equilibrium with water under the adiabatic saturation process for heat and mass transfer. However, Figure 7 shows that the $\eta_{\mathrm{en}}$ is generally larger than 100 . The Figure also reveals that the highest $\eta_{\mathrm{en}}$ that can be obtained is 1.86 at $T_{\mathrm{w}, 1}=28^{\circ} \mathrm{C}, T_{\mathrm{a}, 1}$ $=30^{\circ} \mathrm{C}, R H_{\mathrm{a}, 1}=40 \%, m_{\mathrm{a}, 1}=7 \mathrm{~kg} / \mathrm{h}$, and $m_{\mathrm{w}, 1}=32 \mathrm{~kg} / \mathrm{h}$. This result proves that the actual process is slightly different from the adiabatic saturation process, especially for high air temperature and relative humidity.
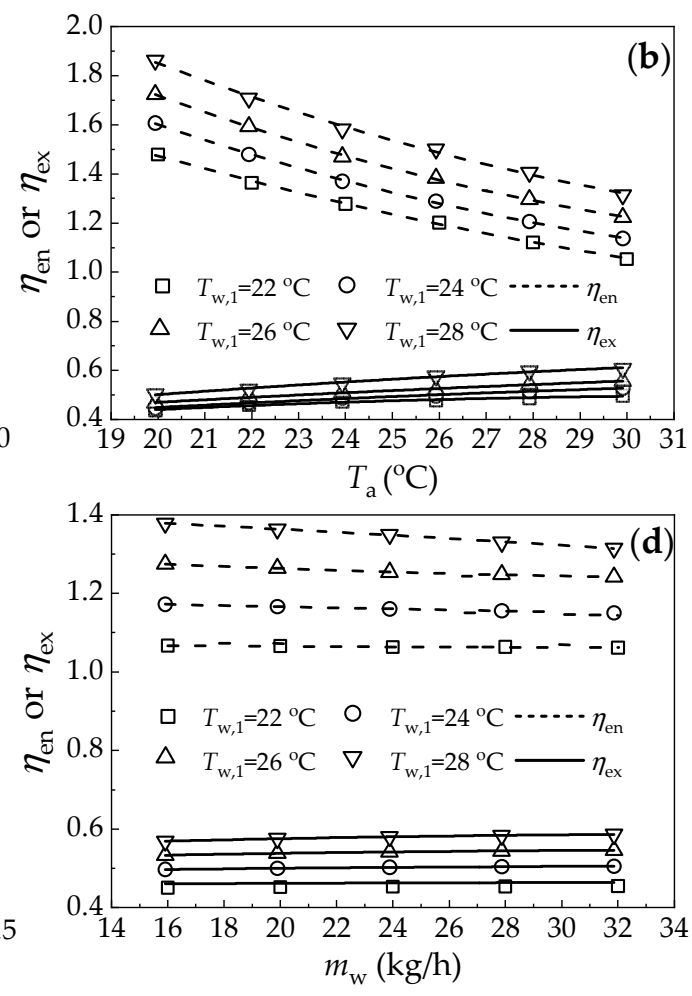

Figure 7. Effect of operating conditions on the exergy efficiency $\left(\eta_{e x}\right)$ and energy efficiency $\left(\eta_{\text {en }}\right):($ a) inlet air relative humidity, (b) inlet air dry bulb temperature, (c) air mass flow rate, and (d) water mass flow rate. 


\subsection{Performance Comparison of Humidifier}

Data for different humidification materials are obtained from the literature. The differential air moisture content and humidification efficiency of these materials under relevant operating conditions are compared with the data obtained in the work of this paper, as shown in Table 3. All systems are chosen to operate under the same conditions as far as possible to compare the measured performance parameters of the humidification materials tested in the literature fairly. Table 3 shows that the studied hollow fiber membrane humidifier had a substantially higher value of humidity ratio increase than other types of humidifying pads tested in the literature [14, 36-41]. Moreover, the hollow fiber membrane humidifier is more efficient in humidifying the volcanic tuff (value of $80.17 \%$ ) than the volcanic tuff (value of $81.98 \%$ ), and coarse pumice in the literature [39] stones (value of $87.37 \%$ ) is slightly low. Thus, the current hollow fiber membranes generally show higher performance parameters compared with other types of humidification pads in the literature. This finding indicates that hollow fiber membranes are reliable and suitable as gas humidification materials.

Table 3. Comparisons with previous different types of evaporation materials on air humidity ratio and humidification efficiency.

\begin{tabular}{|c|c|c|c|c|c|c|c|c|}
\hline Refs & Material type & $A\left(\mathrm{~m}^{2}\right)$ & $m_{\mathrm{a}}(\mathrm{m} / \mathrm{s})$ & $\overline{T_{\mathrm{w}}}$ & $m_{\mathrm{w}}(\mathrm{kg} / \mathrm{h})$ & $\Delta P(\mathbf{P a})$ & $\Delta \omega(\mathrm{g} / \mathrm{kg})$ & $\varepsilon_{\mathrm{h}}(\%)$ \\
\hline Present work & counter flow hollow fiber membrane module & 0.3925 & 0.34 & 26 & 32 & 21 & 10.13 & 80.17 \\
\hline$[14]$ & $\begin{array}{l}\text { rectangular cross-flow hollow fiber } \\
\text { membrane module }\end{array}$ & 4.781 & 0.40 & 23 & 50 & 6 & 5.67 & 61.37 \\
\hline [36] & plastic mesh & 0.3500 & 0.20 & 23 & 0.467 & 0.2 & 2.85 & 51.07 \\
\hline$[37]$ & cellulose (bee-hive) & 0.1920 & 1.00 & 30 & 0.167 & 8 & 7.36 & - \\
\hline [38] & eucalyptus fibers & 0.0784 & 0.30 & - & - & - & 5.42 & 43.51 \\
\hline \multirow[t]{3}{*}{ [39] } & shading net & 0.25 & 0.60 & 25 & 0.029 & 5.2 & 2.76 & 30.99 \\
\hline & coarse pumice stones & 0.25 & 0.60 & 25 & 0.029 & 8.7 & 7.78 & 87.37 \\
\hline & fine pumice stones & 0.25 & 0.60 & 25 & 0.029 & 15.6 & 6.17 & 69.29 \\
\hline$[40]$ & parallel-plate membrane & 0.01 & 0.018 & 24 & 0.0096 & 17 & - & 64.89 \\
\hline [41] & fiber bundles in a spindle shape & 0.1885 & 0.36 & 25 & 0.03 & - & 3.57 & 25.22 \\
\hline
\end{tabular}

\section{Conclusions}

The performance of the hollow fiber membrane humidifier is experimentally studied under various operating conditions (air mass flow rate, water mass flow rate, water temperature, air temperature, and relative humidity) based on energy and exergy analysis. Air humidity ratio rise, air temperature drop, SEC of air humidification capacity and humidification, exergy, and energy efficiencies are used to evaluate and quantify the humidification performance of the hollow fiber membrane humidifier.

The results indicated the hollow fiber membrane humidifier cooled and humidified the process air stream. The humidification capacity can be improved for a high water temperature and a low air velocity, especially for air with low temperature and relative humidity. Such an improvement can be attributed to the effect of the increase in the heat transfer rate, mass transfer rate, and contact time for the air-water interface. In addition, the water mass flow rate showed a marginal impact on the humidification effectiveness.

The exergy efficiency is significantly enhanced with the increase in air temperature, water temperature, and relative humidity and remained almost constant with the increase in the air mass flow rate and water mass flow rate. Additional water vapor absorbed in air and large temperature drop generally lead to large heat and mass transfer between the water and air and substantial exergy loss in these processes. Therefore, the exergy efficiency is negatively affected due to the increase in the humidification and air cooling performance of the hollow fiber membrane humidifier.

\section{Acknowledgements}

The author would like to thank the the National Natural Science Foundation of China, No. 51566002; Guangxi Natural Science Fundation, No. 2018GXNSFAA281347; Guangxi Key Laboratory of Manufacturing System and Advanced Technology Foundation, grant number 19050-44-001Z.

\section{References}

[1] KNEIFEL, K.; NOWAK, S.; ALBRECHT, W.; HILKE, R.; JUST, R.; PEINEMANN, K., Hollow fiber membrane contactor for air humidity control: Modules and membranes. J Membrane Sci 2006, 276, (1-2), 241-251.

[2] Cahalan, T.; Rehfeldt, S.; Bauer, M.; Becker, M.; Klein, H., Experimental set-up for analysis of membranes used in external membrane humidification of PEM fuel cells. Int J Hydrogen Energ 2016, 41, (31), 13666-13677.

[3] Dijkink, B. H.; Tomassen, M. M.; Willemsen, J. H. A.; van Doorn, W. G., Humidity control during bell pepper storage, using a hollow fiber membrane contactor system. Postharvest Biol Tec 2004, 32, (3), 311-320.

[4] Li, G.; Qi, R.; Zhang, L., Performance study of a solar-assisted hollow-fiber-membrane-based air humidification dehumidification desalination system: Effects of membrane properties. Chem Eng Sci 2019, 206, 164-179.

[5] ASHRAE, ANSI/ASHRAE Standard 55-2017: Thermal Environmental Conditions for Human Occupancy. In 1041-2336, SSPC, Ed ASHRAE: Atlanta, 2017. 
[6] Wolkoff, P., Indoor air humidity, air quality, and health - An overview. Int J Hyg Envir Heal 2018, 221, (3), 376-390.

[7] Jesswein, I.; Hirth, T.; Schiestel, T., Continuous dip coating of PVDF hollow fiber membranes with PVA for humidification. J Membrane Sci 2017, 541, 281-290.

[8] Golinko, I.; Drevetskiy, V., Mathematical Model of Heat-and-Mass Transfer for Steam Humidifier. Modeling, Control and Information Technologies 2019, (3), 35-36.

[9] Feng, Z.; Zhou, X.; Xu, S.; Ding, J.; Cao, S., Impacts of humidification process on indoor thermal comfort and air quality using portable ultrasonic humidifier. Build Environ 2018, 133, 62-72

[10] Chen, J.; Han, D.; He, W.; Liu, Y.; Gu, J., Theoretical and experimental analysis of the thermodynamic and economic performance for a packed bed humidifier. Energ Convers Manage 2020, 206, 112497.

[11] Eder, E.; Preißinger, M., Experimental analysis of the humidification of air in bubble columns for thermal water treatment systems. Exp Therm Fluid Sci 2020, 115, 110063.

[12] Xu, Z.; Xiao, Y.; Wang, Y., Experimental and theoretical studies on air humidification by a water spray at elevated pressure. Appl Therm Eng 2007, 27, (14-15), 2549-2558.

[13] Bazhenov, S. D.; Bildyukevich, A. V.; Volkov, A. V., Gas-Liquid Hollow Fiber Membrane Contactors for Different Applications. Fibers 2018, 6, (4), 76.

[14] Zhang, L., Coupled heat and mass transfer in an application-scale cross-flow hollow fiber membrane module for air humidification. Int J Heat Mass Tran 2012, 55, (21-22), 5861-5869.

[15] Johnson, D. W.; Yavuzturk, C.; Pruis, J., Analysis of heat and mass transfer phenomena in hollow fiber membranes used for evaporative cooling. J Membrane Sci 2003, 227, (1-2), 159-171.

[16] Pandey, R.; Lele, A., Modelling of water-to-gas hollow fiber membrane humidifier. Chem Eng Sci 2018, 192, 955-971.

[17] Chiari, A., Air humidification with membrane contactors: experimental and theoretical results. International journal of ambient energy 2000, 21, (4), 187-195.

[18] Bergero, S.; Chiari, A., Experimental and theoretical analysis of air humidification/dehumidification processes using hydrophobic capillary contactors. Appl Therm Eng 2001, 21, (11), 1119-1135.

[19] Zhang, L.; Huang, S., Coupled heat and mass transfer in a counter flow hollow fiber membrane module for air humidification. Int J Heat Mass Tran 2011, 54, (5-6), 1055-1063.

[20] Zhang, L.; Li, Z.; Zhong, T.; Pei, L., Flow maldistribution and performance deteriorations in a cross flow hollow fiber membrane module for air humidification. J Membrane Sci 2013, 427, 1-9.

[21] Huang, S.; Yang, M., Longitudinal fluid flow and heat transfer between an elliptical hollow fiber membrane tube bank used for air humidification. Appl Energ 2013, 112, 75-82.

[22] Bakeri, G.; Naeimifard, S.; Matsuura, T.; Ismail, A. F., A porous polyethersulfone hollow fiber membrane in a gas humidification process. Rsc Adv 2015, 5, (19), 14448-14457.
[23] Bakeri, G., A Comparative Study on the Application of Porous PES and PEI Hollow Fiber Membranes in Gas Humidification Process. Journal of Membrane Science \& Research 2019, 5, 11-19.

[24] Banat, F.; Jwaied, N., Exergy analysis of desalination by solar-powered membrane distillation units. Desalination 2008, 230, (1-3), 27-40.

[25] Ni, M.; Leung, M. K. H.; Leung, D. Y. C., Energy and exergy analysis of hydrogen production by a proton exchange membrane (PEM) electrolyzer plant. Energ Convers Manage 2008, 49, (10), 2748-2756.

[26] Al-Sulaiman, F. A., Assessment of next generation refrigerants for air conditioning systems integrated with air-membrane heat and mass exchangers. Energ Convers Manage 2017, 154, 344-353.

[27] Huang, S.; Li, N.; Low, E.; Xiao, L.; Liang, C., Entropy and exergy analysis of a liquid-liquid air-gap hollow fiber membrane contactor. Int J Therm Sci 2020, 158, 106543.

[28] Liu, G.; Qin, Y.; Yin, Y.; Bian, X.; Kuang, C., Thermodynamic modeling and exergy analysis of proton exchange membrane fuel cell power system. Int J Hydrogen Energ 2020, 45, (54), 29799-29811.

[29] Liang, C.; Li, N.; Huang, S., Entropy and exergy analysis of an internally-cooled membrane liquid desiccant dehumidifier. Energy 2020, 192, 116681.

[30] Liang, C.; Zeng, S., Multi-Objective Design Optimization of Hollow Fiber Membrane-Based Liquid Desiccant Module Using Particle Swarm Optimization Algorithm. Heat Transfer Eng 2017, 1-11.

[31] J. R, T.; W, T., An Introduction to Error Analysis: The Study of Uncertainties in Physical Measurements, 2nd ed. University Science Books 1997.

[32] Dincer, I.; Rosen, M. A., Exergy Analysis of Heating, Refrigerating, and Air Conditioning. Elsevier: 2015; p 1-42.

[33] Chengqin, R.; Nianping, L.; Guangfa, T., Principles of exergy analysis in HVAC and evaluation of evaporative cooling schemes. Build Environ 2002, 37, (11), 1045-1055.

[34] Kanoglu, M.; Dincer, I.; Rosen, M., Exergy analysis of psychrometric processes for HVAC\&R applications, ASHRAE Trans 113 part 2. 2007; p 172-180.

[35] Ratlamwala, T. A. H.; Dincer, I., Efficiency assessment of key psychometric processes. International Journal of Refrigeration 2013, 36, (3), 1142-1153.

[36] Martínez, P.; Ruiz, J.; Martínez, P. J.; Kaiser, A. S.; Lucas, M., Experimental study of the energy and exergy performance of a plastic mesh evaporative pad used in air conditioning applications. Appl Therm Eng 2018, 138, 675-685.

[37] Nada, S. A.; Fouda, A.; Mahmoud, M. A.; Elattar, H. F., Experimental investigation of energy and exergy performance of a direct evaporative cooler using a new pad type. Energ Buildings 2019, 203, 109449.

[38] Abohorlu Doğramacı, P.; Riffat, S.; Gan, G.; Aydın, D., Experimental study of the potential of eucalyptus fibres for evaporative cooling. Renew Energ 2019, 131, 250-260.

[39] Gunhan, T.; Demir, V.; Yagcioglu, A. K., Evaluation of the Suitability of Some Local Materials as Cooling Pads. Biosyst Eng 2007, 96, (3), 369-377. 
[40] Yang, M.; Huang, S.; Yang, X., Experimental investigations of a quasi-counter flow parallel-plate membrane contactor used for air humidification. Energ Buildings 2014, 80, 640-644.
[41] Chen, X.; Su, Y.; Aydin, D.; Zhang, X.; Ding, Y.; Reay, D.; Law, R.; Riffat, S., Experimental investigations of polymer hollow fibre integrated evaporative cooling system with the fibre bundles in a spindle shape. Energ Buildings 2017, 154. 